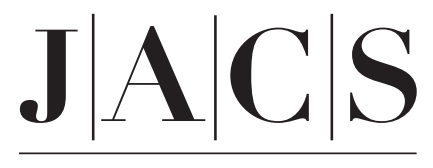

A R T I C L E S

Published on Web 01/11/2007

\title{
New Members of a Class of Iron-Thiolate-Nitrosyl Compounds: Trinuclear Iron-Thiolate-Nitrosyl Complexes Containing $\mathrm{Fe}_{3} \mathrm{~S}_{6}$ Core
}

\author{
I-Jui Hsu, ${ }^{\dagger}$ Chung-Hung Hsieh, ${ }^{\ddagger}$ Shyue-Chu Ke, ${ }^{*} \S$ Kuo-An Chiang, ${ }^{\S}$ Jenn-Min Lee, ${ }^{\perp}$ \\ Jin-Ming Chen, ${ }^{\perp}$ Ling-Yun Jang, ${ }^{\perp}$ Gene-Hsiang Lee, ${ }^{\dagger}{ }^{\top}$ Yu Wang, ${ }^{*, \dagger}$ \\ and Wen-Feng Liaw ${ }^{*}$, \\ Contribution from the Department of Chemistry, National Tsing Hua University, Hsinchu 30013, \\ Taiwan, Department of Chemistry, National Taiwan University, Taipei, Taiwan, Department of \\ Physics, National Dong Hwa University, Hualien, Taiwan, and National Synchroton \\ RaditionResearch Center, Hsinchu, Taiwan
}

Received July 27, 2006; E-mail: wfliaw@mx.nthu.edu.tw; wangyu@ntu.edu.tw; ke@mail.ndhu.edu.tw

\begin{abstract}
The neutral trinuclear iron-thiolate-nitrosyl, $\left[(\mathrm{ON}) \mathrm{Fe}\left(\mu-\mathrm{S}, \mathrm{S}-\mathrm{C}_{6} \mathrm{H}_{4}\right)\right]_{3}(\mathbf{1})$, and its oxidation product, $\left[(\mathrm{ON}) \mathrm{Fe}\left(\mu-\mathrm{S}, \mathrm{S}-\mathrm{C}_{6} \mathrm{H}_{4}\right)\right]_{3}\left[\mathrm{PF}_{6}\right](2)$, were synthesized and characterized by $\mathrm{IR}$, X-ray diffraction, X-ray absorption, electron paramagnetic resonance (EPR), and magnetic measurement. The five-coordinated, square pyramidal geometry around each iron atom in complex 1 remains intact when complex 1 is oxidized to yield complex 2. Magnetic measurements and EPR results show that there is only one unpaired electron in complex $1\left(S_{\text {total }}=1 / 2\right)$ and no unpaired electron $\left(S_{\text {total }}=0\right)$ in $\mathbf{2}$. The detailed geometric comparisons between complexes 1 and 2 provide understanding of the role that the unpaired electron plays in the chemical bonding of this trinuclear complex. Significant shortening of the $\mathrm{Fe}-\mathrm{Fe}, \mathrm{Fe}-\mathrm{N}$, and $\mathrm{Fe}-\mathrm{S}$ distances around $\mathrm{Fe}(1)$ is observed when complex $\mathbf{1}$ is oxidized to 2 . This result implicates that the removal of the unpaired electron does induce the strengthening of the $\mathrm{Fe}-\mathrm{Fe}, \mathrm{Fe}-\mathrm{N}$, and $\mathrm{Fe}-\mathrm{S}$ bonds in the $\mathrm{Fe}(1)$ fragment. A significant shift of the $v_{\mathrm{NO}}$ stretching frequency from $1751 \mathrm{~cm}^{-1}(1)$ to $1821,1857 \mathrm{~cm}^{-1}(2)(\mathrm{KBr})$ also indicates the strengthening of the $\mathrm{N}-\mathrm{O}$ bonds in complex 2 . The EPR, X-ray absorption, magnetic measurements, and molecular orbital calculations lead to the conclusion that the unpaired electron in complex $\mathbf{1}$ is mainly allocated in the $\mathrm{Fe}(1)$ fragment and is best described as $\{\mathrm{Fe}(1) \mathrm{NO}\}^{7}$, so that the unpaired electron is delocalized between Fe and $\mathrm{NO}$ via $\mathrm{d}-\pi^{*}$ orbital interaction; some contributions from [Fe(2) NO] and $[\mathrm{Fe}(3) \mathrm{NO}]$ as well as the thiolates associated with $\mathrm{Fe}(1)$ are also realized. According to $\mathrm{MO}$ calculations, the spin density of complex 1 is predominately located at the Fe atoms with $0.60,-0.15$, and 0.25 at $\mathrm{Fe}(1), \mathrm{Fe}(2)$, and $\mathrm{Fe}(3)$, respectively.
\end{abstract}

\section{Introduction}

Iron-sulfur-nitrosyl complexes have attracted considerable interest stimulated by (i) the reported formation of protein-bound dinitrosyl-iron complexes (DNICs) in the anaerobic reaction of Chromatium vinosum high-potential iron protein with nitric oxide, ${ }^{1,2}$ (ii) the observation of $\left[\mathrm{Fe}_{4} \mathrm{~S}_{3}(\mathrm{NO})_{7}\right]^{-}$acting as an inhibitor of Clostridium sporogenes in culture medium, ${ }^{3}$ (iii) the metal nitrosyl complexes being employed to serve as nitric oxide delivery reagents to biological targets, ${ }^{4,5}$ and (iv) the versatile bonding properties between metal and NO. ${ }^{4-17}$

\footnotetext{
$\ddagger$ National Tsing Hua University.

National Taiwan University.

$\S$ National Dong Hwa University.

${ }^{\perp}$ National Synchroton Radition Research Center.

(1) (a) Foster, M. W.; Cowan, J. A. J. Am. Chem. Soc. 1999, 121, 4093. (b) Morse, R. H.; Chan, S. I. J. Biol. Chem. 1980, 255, 7876. (c) Reginato, N.; McCrory, C. T. C.; Pervitsky, D.; Li, L. J. Am. Chem. Soc. 1999, 121, 10217.

(2) (a) Cooper, C. E. Biochim. Biophys. Acta 1999, 1411, 290. (b) Vanin, A. F.; Stukan, R. A.; Manukhina, E. B. Biochim. Biophys. Acta 1996, 1295, 5 .

(3) Cammack, R.; Joannou, C. L.; Cui, X.-Y.; Martinez, C. T.; Maraj, S. R.; Hughes, M. N. Biochim. Biophys. Acta 1999, 1411, 475.
}

10.1021/ja065401e CCC: $\$ 37.00$ @ 2007 American Chemical Society
Due to the existence of the potential electron-transfer series of 1,2-benzenedithiolate, ${ }^{6}$ and the "non-innocent" character of $\mathrm{NO}$ acting as $\mathrm{NO}^{+}, \mathrm{NO}^{-}$and the paramagnetic neutral $\mathrm{NO} \bullet$ radical, ${ }^{7}$ determination of the formal oxidation state of transition metal and NO in the 1,2-benzenedithiolate-metal nitrosyl complexes becomes rather complicated. Thus, the metal-NO unit is generally designated as $\left\{\mathrm{M}(\mathrm{NO})_{x}\right\}^{n}$ ( $\mathrm{M}=$ transition metal), the Enemark-Feltham notation, ${ }^{8}$ which stresses the well-

(4) (a) Sellers, V. M.; Johnson, M. K.; Dailey, H. A. Biochemistry 1996, 35, 2699. (b) Scott, M. J.; Holm, R. H. Angew. Chem., Int. Ed. Engl. 1993, 32,564 .

(5) (a) Ford, P. C.; Bourassa, J.; Miranda, K.; Lee, B.; Lorkovic, I.; Boggs, S.; Kudo, S.; Laverman, L. Coord. Chem. Rev. 1998, 171, 185. (b) Ford, P. C.; Lorkovic, I. M. Chem. Rev. 2002, 102, 993. (c) Butler, A. R.; Megson, I. L. Chem. Rev. 2002, 102, 1155

(6) (a) Pierpont, C. G.; Buchanan, R. M. Coord. Chem. Rev. 1981, 38, 45. (b) Attia, A. S.; Pierpont, C. G. Inorg. Chem. 1995, 34, 1172. (c) Lim, B. S Fomitchev, D. V.; Holm, R. H. Inorg. Chem. 2001, 40, 4257. (d) Hayton, T. W.; Legzdins, P.; Sharp, W. B. Chem. Rev. 2002, 102, 935. (e) Wang, P. G.; Xian, M.; Tang, X.; Wu, X.; Wen, Z.; Cai, T.; Janczuk, A. J. Chem. Rev. 2002, 102, 1091

(7) (a) Franz, K. J.; Lippard, S. J. J. Am. Chem. Soc. 1998, 120, 9034 (b) Brown, C. A.; Pavlosky, M. A.; Westre, T. E.; Zhang, Y.; Hedman, B.; Hodgson, K. O.; Solomon, E. I. J. Am. Chem. Soc. 1995, 117, 715. (c) Mingos, D. M. P.; Sherman, D. J. Adv. Inorg. Chem. 1989, 34, 293. 
known covalency and delocalization in the $\mathrm{M}(\mathrm{NO})_{x}$ unit without being committed a certain formal oxidation state on either $\mathrm{M}$ or NO.

Recently, some interesting compounds of NO binding metal centers as $\mathrm{M}-\mathrm{NO}^{+} / \mathrm{M}-\mathrm{NO}^{-} / \mathrm{M}-\mathrm{NO} \bullet$ have been reported. ${ }^{5,6,9-17}$ Lippard and co-workers reported that the Fe in complex [(NO)Fe(TC-5,5)] (TC-5,5 = tropocoronand) adopts a trigonal bipyramidal, low-spin state with a linearly coordinated nitroxy ( $\mathrm{Fe}-$ $\left.\mathrm{N}-\mathrm{O}=174.3(4)^{\circ}\right)$ group containing a short $\mathrm{Fe}-\mathrm{N}$ distance of 1.670(4) $\AA{ }^{9}{ }^{9}\left\{\mathrm{Fe}^{\mathrm{III}}\left(\mathrm{NO}^{-}\right)\right\} .{ }^{7}$ The electronic structure of $[\mathrm{Fe}-$ $\left.\left(\mathrm{H}_{2} \mathrm{O}\right)_{5}(\mathrm{NO})\right]^{2+}$ is best described as $\left[\mathrm{Fe}^{\mathrm{III}}\left(\mathrm{H}_{2} \mathrm{O}\right)_{5}\left(\mathrm{NO}^{-}\right)\right]^{2+}$ in which high-spin $\mathrm{Fe}^{\mathrm{III}}$ is antiferromagnetically coupled with $\mathrm{NO}^{-}$ $(S=1)$ to yield the observed spin quartet ground state $(S=$ $3 / 2) .{ }^{10}$ Interestingly, the experimental and theoretical studies show that $\left[(\mathrm{NC})_{5} \mathrm{Fe}(\mathrm{NO})\right]^{3-}$ contains delocalized oxidation levels of the metal and ligand, namely a resonance hybrid of $\left[(\mathrm{NC})_{5} \mathrm{Fe}^{\mathrm{II}}(\mathrm{NO} \bullet)\right]^{3-}$ and $\left[(\mathrm{NC})_{5} \mathrm{Fe}^{\mathrm{I}}\left(\mathrm{NO}^{+}\right)\right]^{3-} .{ }^{11}$ Also, the $\mathrm{Fe}^{\mathrm{III}}$ center binds $\mathrm{NO}$ in the form of $\mathrm{Fe}^{\mathrm{II}}-\mathrm{NO}^{+}$, and $\mathrm{Co}^{\mathrm{II}}$ binds $\mathrm{NO}$ in the form of $\mathrm{Co}^{\mathrm{III}}-\mathrm{NO}^{-}$in metmyoglobin and reduced vitamin $\mathrm{B}_{12}$, respectively. ${ }^{12,13}$

In spite of a large number of mononuclear/tetranuclear ironthiolate-nitrosyl complexes, ${ }^{14-17}$ examples of trinuclear ironNO complexes surrounded by thiolate ligands are limited. ${ }^{15}$ By application of nitrosylation, we have prepared the mononuclear $[\mathrm{PPN}]\left[(\mathrm{ON}) \mathrm{Fe}\left(\mathrm{S}, \mathrm{S}-\mathrm{C}_{6} \mathrm{H}_{4}\right)_{2}\right] .{ }^{17}$ The neutral, paramagnetic trinuclear iron-thiolate-nitrosyl complex, $\left[(\mathrm{ON}) \mathrm{Fe}\left(\mu-\mathrm{S}, \mathrm{S}-\mathrm{C}_{6} \mathrm{H}_{4}\right)\right]_{3}$ (1), was produced upon the protonation of the mononuclear iron-thiolate-nitrosyl [PPN][(NO)Fe $\left.\left(\mathrm{S}, \mathrm{S}-\mathrm{C}_{6} \mathrm{H}_{4}\right)_{2}\right]$ by $\mathrm{HBF}_{4}$ in THF. Oxidation of complex 1 in $\mathrm{CH}_{2} \mathrm{Cl}_{2}$ yields the diamagnetic trinuclear complex $\left[(\mathrm{ON}) \mathrm{Fe}\left(\mu-\mathrm{S}, \mathrm{S}-\mathrm{C}_{6} \mathrm{H}_{4}\right)\right]_{3}\left[\mathrm{PF}_{6}\right](2)$. Crystalline samples of complexes $\mathbf{1}$ and $\mathbf{2}$ were characterized by IR, UVvis, ${ }^{1} \mathrm{H}$ NMR, EPR spectroscopy, X-ray diffraction study, magnetic susceptibility measurements, and Fe/S/N K-edge X-ray absorption spectroscopy (XAS).

\section{Results and Discussion}

Synthesis. A new member of a class of iron-sulfur-nitrosyl clusters, the neutral trinuclear $\mathrm{Fe}$-thiolate-nitrosyl complex $\left[(\mathrm{ON}) \mathrm{Fe}\left(\mu-\mathrm{S}, \mathrm{S}-\mathrm{C}_{6} \mathrm{H}_{4}\right)\right]_{3}$ (1) containing three bridging $[\mathrm{S}, \mathrm{S}$ $\left.\mathrm{C}_{6} \mathrm{H}_{4}\right]^{2-}$ ligands bound to three Fe's in a bidentate manner was obtained when 1 equiv of $\mathrm{HBF}_{4}$ was added to [PPN][(NO)Fe$\left.\left(\mathrm{S}, \mathrm{S}-\mathrm{C}_{6} \mathrm{H}_{4}\right)_{2}\right]$ in THF and stirred overnight at ambient temper-

(8) Enemark, J. H.; Feltham, R. D. Coord. Chem. Rev. 1974, 13, 339.

(9) Franz, K. J.; Lippard, S. J. J. Am. Chem. Soc. 1999, 121, 10504.

(10) Wanat, A.; Schneppensieper, T.; Stochel, G.; van Eldik, R.; Bill, E.; Wieghardt, K. Inorg. Chem. 2002, 41, 4.

(11) Wanner, M.; Scheiring, T.; Kaim, W.; Slep, L. D.; Baraldo, L. M.; Olabe, J. A. Zalis, S.; Baerends, E. J. Inorg. Chem. 2001, 40, 5704

(12) Laverman, L. E.; Wanat, A.; Oszajca, J.; Stochel, G.; Ford, P. C.; van Eldik, R. J. Am. Chem. Soc. 2001, 123, 285.

(13) Wolak, M.; Stochel, G.; Zahl, A.; Schneppensieper, T.; van Eldik, R. J. Am. Chem. Soc. 2001, 123, 9780.

(14) (a) Chu, C. T.-W.; Dahl, L. F. Inorg. Chem. 1977, 16, 3245. (b) Chu, C. T.-W.; Lo, F. Y.-K.; Dahl, L. F. J. Am. Chem. Soc. 1982, 104, 3409. (c) Goh, C.; Holm, R. H. Inorg. Chim. Acta 1998, 270, 46. (d) Sung, S.-S. Glidewell, C.; Butler, A. R.; Hoffmann, R. Inorg. Chem. 1985, 24, 3856

(15) Butler, A. R.; Glidewell, C.; Li, M.-H. Adv. Inorg. Chem. 1988, 32, 335

(16) (a) Tsai, F.-T.; Chiou, S.-J.; Tsai, M.-C.; Tsai, M.-L.; Huang, H.-W.; Chiang, M.-H.; Liaw, W.-F. Inorg. Chem. 2005, 44, 5872. (b) Tsai, M.-L.; Chen, C.-C.; Hsu, I.-J.; Ke, S.-C.; Hsieh, C.-H.; Chiang, K.-A.; Lee, G.-H.; Wang, Y.; Liaw, W.-F. Inorg. Chem. 2004, 43, 5159. (c) Chen, H.-W.; Lin, C.-W.; Chen, C.-C.; Yang, L.-B.; Chiang, M.-H.; Liaw, W.-F. Inorg. Chem. 2005, 44, 3226. (d) Hung, M.-C.; Tsai, M.-C.; Lee, G.-H.; Liaw, W.-F. Inorg. Chem. 2006, 45, 6041. (e) Lu, T.-T.; Chiou, S.-J.; Chen, C.-Y.; Liaw, W.-F. Inorg. Chem. 2006, 45, 8799. (f) Tsai, M.-L.; Liaw, W.-F. Inorg. Chem. 2006, 45, 6583.

(17) (a) Lee, C.-M.; Hsieh, C.-H.; Dutta, A.; Lee, G.-H.; Liaw, W.-F. J. Am Chem. Soc. 2003, 125, 11492. (b) Lee, C.-M.; Chen, C.-H.; Chen, H.-W.; Hsu, J.-L.; Lee, G.-H.; Liaw, W.-F. Inorg. Chem. 2005, 44, 6670.
Scheme 1

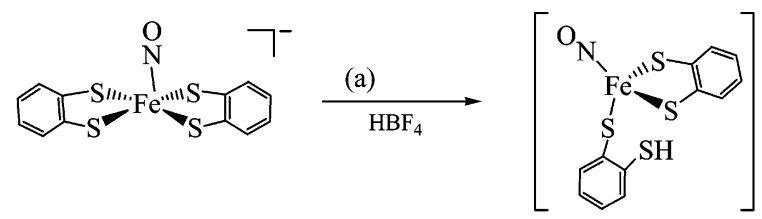

(A)

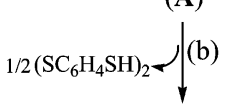

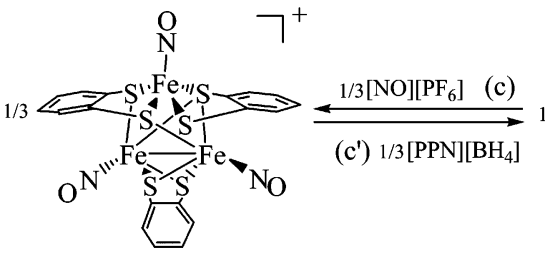

(2)

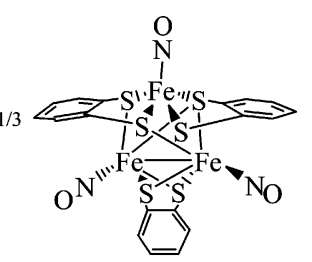

(1) ature (Scheme 1a-c). ${ }^{17,18}$ Complex $\mathbf{1}$ was isolated as a greenish brown solid. The IR spectrum of complex 1 reveals one broad absorption band for the NO groups at $1751 \mathrm{~cm}^{-1}(\mathrm{KBr})$, reflecting qualitatively the closely equivalent electronic environment of three $\left[\mathrm{Fe}(\mathrm{NO}) \mathrm{S}_{4}\right]$ fragments. ${ }^{15,17}$ Complex 1 exhibits a diagnostic ${ }^{1} \mathrm{H}$ NMR spectrum with the 1,2-benzenedithiolate proton resonances well removed from the diamagnetic region. The protons resonate upfield, 2.60 (br), -0.192 (br) ppm, which is consistent with the paramagnetic species.

The formation of complex 1 from the protonation of [(NO)$\left.\mathrm{Fe}\left(\mathrm{S}, \mathrm{S}-\mathrm{C}_{6} \mathrm{H}_{4}\right)_{2}\right]^{-}$can be interpreted as coordinative association of three $\left[(\mathrm{NO}) \mathrm{Fe}\left(\mathrm{S}, \mathrm{S}-\mathrm{C}_{6} \mathrm{H}_{4}\right)\right]$ motifs, where 1,2-benzenedithiolates served as bridging ligands between two $\mathrm{Fe}$ atoms. The plausible reaction path is given in Scheme 1a,b; the protonation of one dithiolate ligand of complex $\left[(\mathrm{NO}) \mathrm{Fe}\left(\mathrm{S}, \mathrm{S}-\mathrm{C}_{6} \mathrm{H}_{4}\right)_{2}\right]^{-}$would yield an unstable intermediate, $\left[(\mathrm{NO}) \mathrm{Fe}\left(\mathrm{S}-\mathrm{C}_{6} \mathrm{H}_{4} \mathrm{SH}\right)\left(\mathrm{S}, \mathrm{S}-\mathrm{C}_{6} \mathrm{H}_{4}\right)\right]$ (A), ${ }^{16 e}$ which may then be accompanied by the reductive elimination of the unidentified disulfide $\left(\mathrm{S}-\mathrm{C}_{6} \mathrm{H}_{4} \mathrm{SH}\right)_{2}$, and presumably, the concomitant coordinative association of [(NO)$\left.\mathrm{Fe}\left(\mathrm{S}, \mathrm{S}-\mathrm{C}_{6} \mathrm{H}_{4}\right)\right]$ motifs led to the formation of $\mathbf{1}$.

Under similar reaction conditions, oxidation of 1 by 1 equiv of [NO] $\left[\mathrm{PF}_{6}\right]$ in $\mathrm{CH}_{2} \mathrm{Cl}_{2}$ under $\mathrm{N}_{2}$ at room temperature yielded a cationic trinuclear iron-thiolate-nitrosyl complex $[(\mathrm{ON}) \mathrm{Fe}$ $\left.\left(\mu-\mathrm{S}, \mathrm{S}-\mathrm{C}_{6} \mathrm{H}_{4}\right)\right]_{3}\left[\mathrm{PF}_{6}\right](2)$, (Scheme 1c) with each iron being ligated by four sulfur atoms as well as one nitrosyl ligand. Similar $\left[\mathrm{Fe}(\mathrm{NO}) \mathrm{S}_{4}\right]$ motifs are found in each iron atom of $\mathbf{1}$ and 2 . In contrast to the one intense broad absorption band in the terminal nitrosyl-stretching region (IR $v_{\mathrm{NO}}$ ) observed in $\mathbf{1}$, the $v_{\mathrm{NO}}$ of 2 shows two discernible nitrosyl bands at $1857 \mathrm{~cm}^{-1}$ and $1821 \mathrm{~cm}^{-1}(\mathrm{KBr})$, which apparently shifted to higher energy from that of 1. Similar to CO (known to serve as an indicator of electron density at iron), the shifts in $v_{\mathrm{NO}}$ frequencies ${ }^{17}$ may reflect a variation in charge on the $\mathrm{Fe}(\mathrm{NO})$ units of 2 . The ${ }^{1} \mathrm{H}$ NMR spectra of 2 show the expected signals $(\delta 7.79(\mathrm{~m}), 7.48$ $(\mathrm{m}), 6.86(\mathrm{~m}), 6.27(\mathrm{~m}) \mathrm{ppm})$ for the 1,2-benzenedithiolate groups' characteristics of diamagnetic species. Interestingly, $\mathbf{1}$ can be re-obtained upon chemical reduction of $\mathbf{2}$ by $[\mathrm{Na}]\left[\mathrm{BH}_{4}\right] /$ [PPN][Cl] in 1:1 stoichiometry in $\mathrm{CH}_{2} \mathrm{Cl}_{2}$ at room temperature (Scheme 1c'). Apparently, $\mathbf{1}$ and $\mathbf{2}$ are chemically interconvertible at ambient temperature.

(18) Hedberg, L.; Hedberg, K.; Satija, S. K.; Swanson, B. I. Inorg. Chem. 1985 , 24,2766 . 


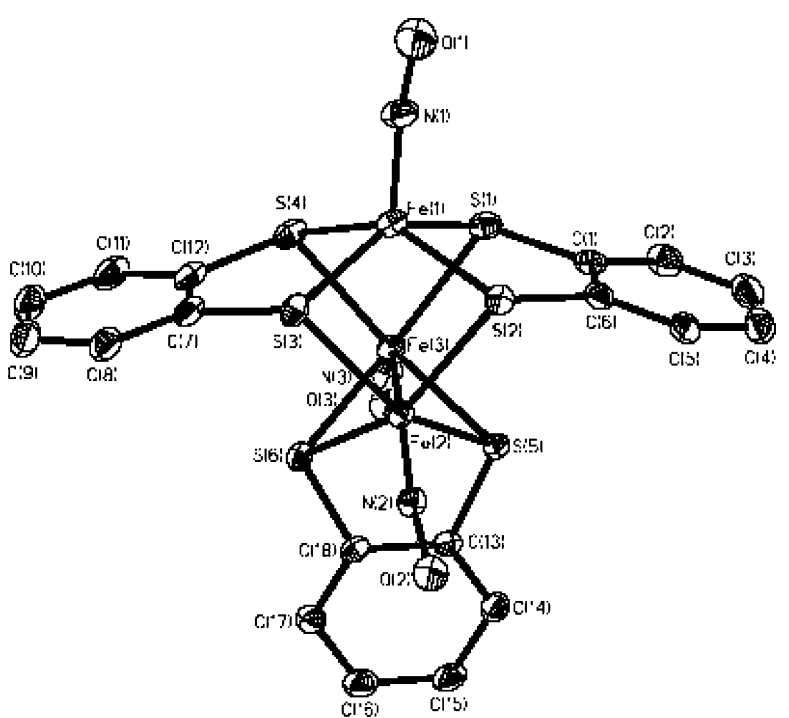

Figure 1. ORTEP drawing with $50 \%$ probability in thermal ellipsoids and labeling scheme of $\mathbf{1}$.

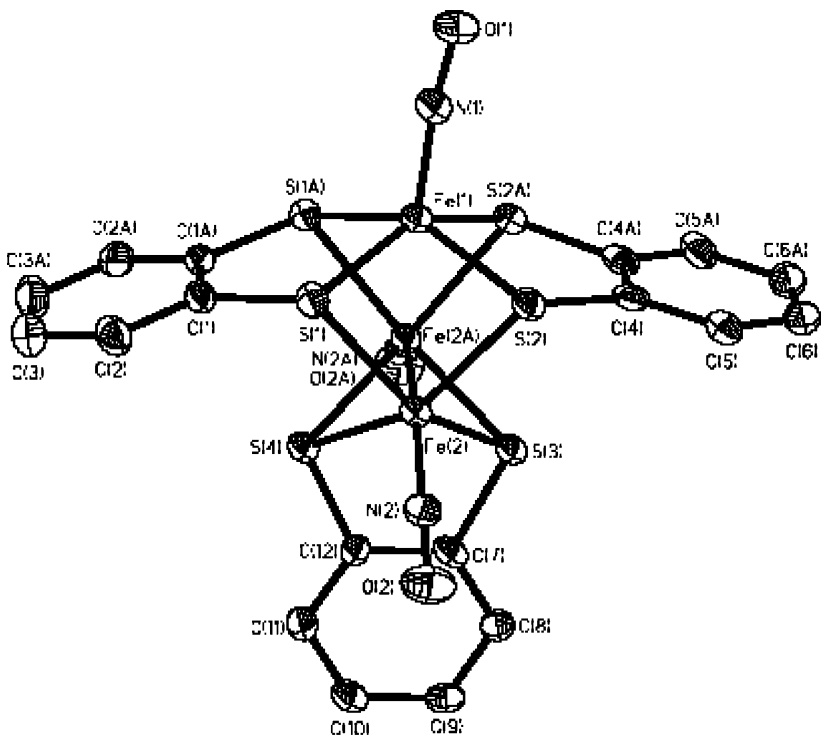

Figure 2. ORTEP drawing with $50 \%$ probability in thermal ellipsoid and labeling scheme of the cation of $\mathbf{2}$.

Structure. The molecular structures of compound $\mathbf{1}$ and $\mathbf{2}$ were determined by single-crystal X-ray diffraction. As shown in Figures 1 and 2, 1 and $\mathbf{2}$ give a high degree of congruency. Both consist of a triangular planar $\mathrm{Fe}_{3}$ core linked by three doubly bridged $\left[\mathrm{S}, \mathrm{S}-\mathrm{C}_{6} \mathrm{H}_{4}\right]^{2-}$ ligands, affording a core composition of $\mathrm{Fe}_{3} \mathrm{~S}_{6}$. Each iron atom is five-coordinated $\left(\mathrm{FeS}_{4} \mathrm{~N}\right)$ and adopts a distorted square pyramidal geometry with a terminal NO ligand at the axial position. Each dithiolate ligand, [S,S$\left.\mathrm{C}_{6} \mathrm{H}_{4}\right]$, is coordinated to two iron atoms through sulfur atoms. For the convenience of discussion, we designate each Fe core $\left(\mathrm{FeS}_{4} \mathrm{~N}\right)$ as fragments 1,2 , and 3 respectively for $\mathrm{Fe}(1), \mathrm{Fe}(2)$, and $\mathrm{Fe}(3)$. There is a crystallographic mirror symmetry passing through $\mathrm{Fe}(1)$ and the midpoint of the other two $\mathrm{Fe}$ atoms for $\mathbf{2}$, but only a pseudo one in $\mathbf{1}$. Bond distances around Fe atoms for both $\mathbf{1}$ and $\mathbf{2}$ are listed in Table 1. The apparently shorter $\mathrm{Fe}(2)-\mathrm{Fe}(3)$ distance of $2.5779(5) \AA$, compared to $\mathrm{Fe}(1)-\mathrm{Fe}-$ (2) and $\mathrm{Fe}(1)-\mathrm{Fe}(3)$ distance of $2.7820(5)$ and $2.7544(5) \AA$, respectively, indicates a greater extent of $\mathrm{Fe}(2)-\mathrm{Fe}(3)$ bonding interaction in 1. A similar observation but to less extent is also
Table 1. Comparison of Bond Distances $(\AA)$ around Fe Atoms in Complexes 1 and $\mathbf{2}$

\begin{tabular}{lllllr}
\hline \multicolumn{1}{c}{ complex 1 } & \multicolumn{1}{c}{$\AA$} & \multicolumn{1}{c}{ complex 2 } & \multicolumn{1}{c}{$\AA$} & \multicolumn{1}{c}{$\Delta^{a}(1-2) \AA$} & $\Delta / \sigma^{b}$ \\
\hline $\mathrm{Fe}(1)-\mathrm{Fe}(2)$ & $2.7820(5)$ & $\mathrm{Fe}(1)-\mathrm{Fe}(2)$ & $2.6724(14)$ & 0.11 & 74 \\
$\mathrm{Fe}(1)-\mathrm{Fe}(3)$ & $2.7544(5)$ & $\mathrm{Fe}(1)-\mathrm{Fe}(3)$ & $2.6724(14)$ & 0.08 & 53 \\
$\mathrm{Fe}(2)-\mathrm{Fe}(3)$ & $2.5779(5)$ & $\mathrm{Fe}(2)-\mathrm{Fe}(3)$ & $2.5694(19)$ & 0.01 & 4 \\
$\mathrm{Fe}(1)-\mathrm{N}(1)$ & $1.681(2)$ & $\mathrm{Fe}(1)-\mathrm{N}(1)$ & $1.646(8)$ & 0.035 & 4 \\
$\mathrm{Fe}(2)-\mathrm{N}(2)$ & $1.661(2)$ & $\mathrm{Fe}(2)-\mathrm{N}(2)$ & $1.648(6)$ & 0.013 & 2 \\
$\mathrm{Fe}(3)-\mathrm{N}(3)$ & $1.680(2)$ & $\mathrm{Fe}(2 \mathrm{~A})-\mathrm{N}(2 \mathrm{~A})$ & $1.648(6)$ & 0.032 & 5 \\
$\mathrm{Fe}(1)-\mathrm{S}(1)$ & $2.2536(7)$ & $\mathrm{Fe}(1)-\mathrm{S}(2)$ & $2.2236(18)$ & 0.030 & 15 \\
$\mathrm{Fe}(1)-\mathrm{S}(2)$ & $2.2349(7)$ & & & 0.011 & 6 \\
$\mathrm{Fe}(1)-\mathrm{S}(3)$ & $2.2614(7)$ & $\mathrm{Fe}(1)-\mathrm{S}(1)$ & $2.2361(18)$ & 0.025 & 13 \\
$\mathrm{Fe}(1)-\mathrm{S}(4)$ & $2.2632(7)$ & & & 0.027 & 14 \\
$\mathrm{Fe}(2)-\mathrm{S}(2)$ & $2.3223(7)$ & $\mathrm{Fe}(2)-\mathrm{S}(2)$ & $2.2781(17)$ & 0.044 & 24 \\
$\mathrm{Fe}(2)-\mathrm{S}(3)$ & $2.3186(7)$ & $\mathrm{Fe}(2)-\mathrm{S}(1)$ & $2.3113(18)$ & 0.007 & 4 \\
$\mathrm{Fe}(2)-\mathrm{S}(5)$ & $2.2660(7)$ & $\mathrm{Fe}(2)-\mathrm{S}(3)$ & $2.260(2)$ & 0.006 & 3 \\
$\mathrm{Fe}(2)-\mathrm{S}(6)$ & $2.2559(7)$ & $\mathrm{Fe}(2)-\mathrm{S}(4)$ & $2.2661(19)$ & -0.010 & 5 \\
$\mathrm{Fe}(3)-\mathrm{S}(1)$ & $2.3335(7)$ & $\mathrm{Fe}(2 \mathrm{~A})-\mathrm{S}(2 \mathrm{~A})$ & $2.2781(17)$ & 0.055 & 30 \\
$\mathrm{Fe}(3)-\mathrm{S}(4)$ & $2.3150(7)$ & $\mathrm{Fe}(2 \mathrm{~A})-\mathrm{S}(1 \mathrm{~A})$ & $2.3113(18)$ & 0.004 & 2 \\
$\mathrm{Fe}(3)-\mathrm{S}(5)$ & $2.2562(6)$ & $\mathrm{Fe}(2 \mathrm{~A})-\mathrm{S}(3)$ & $2.260(2)$ & -0.004 & 2 \\
$\mathrm{Fe}(3)-\mathrm{S}(6)$ & $2.2713(7)$ & $\mathrm{Fe}(2 \mathrm{~A})-\mathrm{S}(4)$ & $2.2661(19)$ & 0.005 & 3 \\
\hline
\end{tabular}

${ }^{a} \Delta$ : The differences between 1 and 2 for the corresponding bond distance. ${ }^{b} \Delta / \sigma$ : The ratio of the differences divided by the standard deviation. The standard deviation is calculated according to the error propagation.

found in 2 with the $\mathrm{Fe}(2)-\mathrm{Fe}(2 \mathrm{~A})$ distance of $2.569(2) \AA$, which is shorter than that of the $\mathrm{Fe}(1)-\mathrm{Fe}(2)$ distance of 2.672(1) $\AA$ ). Variations in $\mathrm{Fe}-\mathrm{S}$ and $\mathrm{Fe}-\mathrm{N}$ distances within the complex are not so noticeable.

The particular geometrical dissimilarities found between $\mathbf{1}$ and $\mathbf{2}$ may lead to the understanding of the effects caused by the removal of one electron. Upon one-electron oxidation from 1 to $\mathbf{2}$, bond distances of fragment 1 (around $\mathrm{Fe}(1)$ ) are shortened the most; e.g. $\mathrm{Fe}(1)-\mathrm{Fe}(2)$ and $\mathrm{Fe}(1)-\mathrm{Fe}(3)$ are shortened by as much as $0.1 \AA$. The $\mathrm{Fe}-\mathrm{S}$ distances change the most $(0.03 \sim 0.06 \AA)$ for one of the thiolates labeled as $S(1)$ and $S(2)$ in Figure 1, a somewhat smaller change $(\sim 0.025 \AA)$ for the one labeled as $S(3)$ and $S(4)$, and practically no change for the one labeled as $\mathrm{S}(5)$ and $\mathrm{S}(6)$. $\mathrm{Fe}-\mathrm{N}$ distances are also shortened somewhat in 2. Detailed comparisons on other distances are listed in Table 1. This result indicates, qualitatively, that the SOMO in $\mathbf{1}$ can be identified as having antibonding character mainly in the $\mathrm{Fe}-\mathrm{Fe}$ bond. Reduced electron density around the $\mathrm{Fe}_{3}$ core and the more effective $\mathrm{Fe}-\mathrm{Fe}$ interactions in 2 may also suppress the $\mathrm{Fe}-\mathrm{N}$ and $\mathrm{Fe}-\mathrm{S}$ antibonding interactions. Although the distance of $\mathrm{N}-\mathrm{O}$ is unaccountable due to the disorder of $\mathrm{O}$ atoms, the significant increase in the $\mathrm{N}-\mathrm{O}$ stretching frequencies in $\mathbf{2}$ does represent the shortening and strengthening of $\mathrm{N}-\mathrm{O}$ bond. The geometry change around $\mathrm{Fe}-$ (1) is obviously the biggest among three Fe atoms, indicating that the removal of the unpaired electron may take place predominantly at fragment 1 . More discussion will be given later in the section of $\mathrm{MO}$ calculation.

Magnetic Measurement. The magnetic measurement of $\mathbf{1}$ is shown in Figure 3. It indicates that the ground state is one unpaired electron with $S_{\text {total }}=1 / 2$. The magnetic moment is slightly temperature dependent and could be fitted by a twodimensional (2D) coupling model with $g=2.01$ and $J=-0.28$. The small negative $J$ value indicates there are weak antiferromagnetic couplings between different fragments.

X-ray Absorption Spectroscopy. The Fe K-edge absorption spectra together with some reference compounds are depicted in the Figure 4. The apparent pre-edge absorption is due to the 


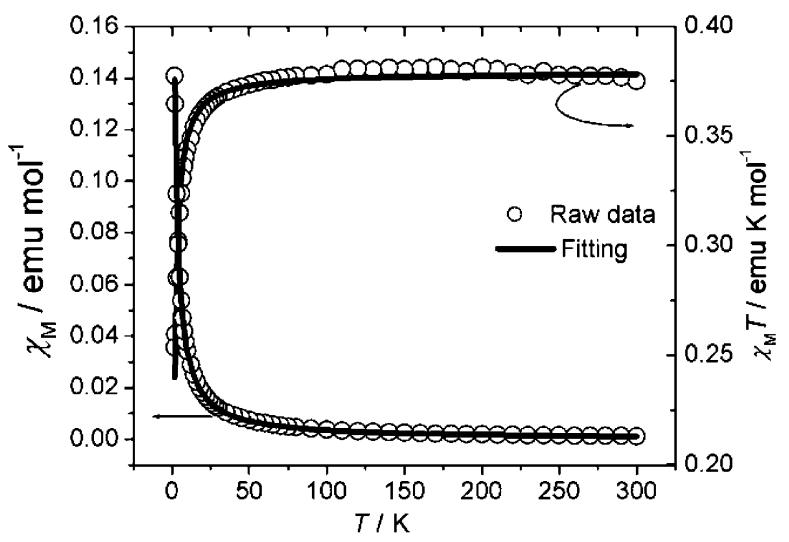

Figure 3. Magnetic measurement of 1. $\chi_{\mathrm{M}}$ and $\chi_{\mathrm{M}} T$ vs $T$; the open circle $(O)$ is from experimental data, and the solid line (-) is the fitted curve.

symmetry-allowed 1 s to $3 \mathrm{~d}$ transition in the distorted square pyramidal local environment of the Fe center with the $d-p$ mixing between $\mathrm{Fe}$ and ligand atoms. The edge absorption is assigned to be the dipole transition from 1 s to $4 p$ orbitals of Fe. Based on the Fe K-edge absorption spectra shown in Figure 4, the formal oxidation state of Fe in $\mathbf{1}$ is definitely higher than that of $\mathrm{Fe}$-foil but lower than those of $\mathrm{FeO}$ and $\mathrm{Fe}_{2} \mathrm{O}_{3}$. It indicates that the average oxidation state of $\mathrm{Fe}$ in $\mathbf{1}$ is the same as that of $(\mathrm{NO}) \mathrm{Fe}\left(\mathrm{S}_{2} \mathrm{CNEt}_{2}\right)_{2}$, which is generally known ${ }^{19}$ as a nitrosyl ligand $\left(\mathrm{NO}^{+}\right)$bonded to a low-spin $\mathrm{d}^{7} \mathrm{Fe}(\mathrm{I})$; thus, the $\mathbf{1}$ is best assigned with the average formal oxidation state of $\mathrm{Fe}(\mathrm{I})$. Take a closer look at the differences between $\mathbf{1}$ and $\mathbf{2}$ in Figure 4; the edge absorption energy of $\mathbf{2}$ is shifted only slightly to higher energy than that of $\mathbf{1}$. Take the maximum values of the first derivative of each spectrum as the edge absorption energy; they are 7119.8 and $7120.4 \mathrm{eV}$ for $\mathbf{1}$ and $\mathbf{2}$, respectively. This may indicate that the one-electron oxidation from $\mathbf{1}$ to 2 does have a small effect on the Fe atoms.

The N K-edge absorption spectra of $\mathbf{1}$ and $\mathbf{2}$ are displayed in Figure 5. Roughly, the peaks around 400-401 and $415 \mathrm{eV}$ are assigned to the transition of $1 \mathrm{~s} \rightarrow \pi^{*}$ and the $1 \mathrm{~s} \rightarrow \sigma^{*}$, respectively. ${ }^{20}$ A single peak at $400.6 \mathrm{eV}$ with $\mathrm{FWHM}=0.96 \mathrm{eV}$, and at $401.1 \mathrm{eV}$ with $\mathrm{FWHM}=0.88 \mathrm{eV}$ for $\mathbf{1}$ and $\mathbf{2}$, respectively, is assigned to be the $1 \mathrm{~s} \rightarrow \pi^{*}$ transition. The single peak is an indication of $\mathrm{NO}^{+}$group because the $\mathrm{NO} \bullet$ radical will generally give two peaks to allow the transitions of two spin states. However, one cannot completely exclude the possibility of having a small portion of the NO radical, where the unpaired electron is delocalized between Fe and NO. The slightly higher $1 \mathrm{~s} \rightarrow \pi^{*}$ transition energy of $\mathbf{2}$ seems to indicate that the one-electron oxidation does have effect on the $\mathrm{N}$ atom of 2 . Shifting to a slightly higher energy of the $1 \mathrm{~s} \rightarrow \pi^{*}$ transition

(19) (a) Goodman, B. A.; Raynor, J. B.; Symons, M. C. R. J. Chem. Soc. (A) 1969, 2572. (b) Gibson, J. F. Nature 1962, 196, 64. (c) McDonald, C. C. Phillips, W. D.; Mower, H. F. J. Am. Chem. Soc. 1965, 87, 3319.

(20) (a) Wright, G. R.; Brion, C. E. J. Electron Spectrosc. 1974, 4, 313. (b) Domke, M.; Remmers, G.; Kaindl, G. Nucl. Instrum. Methods Phys. Res. Sect. B 1994, 87, 173. (c) Stöhr, J.; Jaeger, R. Phys. Rev. B 1982, 26, 4111. (d) Kosugi, N.; Adachi, J.-I.; Shigemasa, E.; Yagishita, A. J. Chem. Phys. 1992, 97, 8842

(21) (a) Szilagyi, R. K.; Lim, B. S.; Glaser, T.; Holm, R. H.; Hedman, B.; Hodgson, K. O.; Solomon, E. I. J. Am. Chem. Soc. 2003, 125, 9158. (b) Szilagyi, R. K.; Bryngelson, P. A.; Maroney, M. J.; Hedman, B.; Hodgson, K. O.; Solomon, E. I. J. Am. Chem. Soc. 2004, 126, 3018. (c) Glaser, T.; Rose, K.; Shadle, S. E.; Hedman, B.; Hodgson, K. O.; Solomon, E. I. J. Am. Chem. Soc. 2001, 123, 442 . position in $\mathbf{2}$ could be rationalized by the stronger bond between $\mathrm{Fe}$ and $\mathrm{N}$ of nitrosyl group due to the more positively charged Fe in 2.

The S K-edge absorption spectra of $\mathbf{1}$ and $\mathbf{2}$ are displayed in Figure 6. According to previous reports, ${ }^{21}$ the peak around 2474 $\mathrm{eV}$ is assigned to be the transition of $1 \mathrm{~s}(\mathrm{~S}) \rightarrow \pi^{*}(\mathrm{C}-\mathrm{S}$ bond $)$, and the peak around $2471 \mathrm{eV}$ is assigned to be the transition of $1 \mathrm{~s}(\mathrm{~S})$ to $3 \mathrm{p}(\mathrm{S})$ mixing with $3 \mathrm{~d}$ orbital of $\mathrm{Fe}$. In comparison with the $1 \mathrm{~s} \rightarrow 3 \mathrm{p}$ transition of both compounds, one peak at 2471.2 $\mathrm{eV}$ is observed for $\mathbf{1}$, but an additional shoulder peak at 2471.7 $\mathrm{eV}$ is found for $\mathbf{2}$. However, the transition energy of $1 \mathrm{~s}(\mathrm{~S}) \rightarrow \pi^{*}$ $(\mathrm{C}-\mathrm{S}$ bond) in $\mathbf{2}$ is only $0.2 \mathrm{eV}$ higher than that of $\mathbf{1}$. This seems to indicate that the one-electron oxidation does affect the $\mathrm{Fe}-\mathrm{S}$ bond more than the $\mathrm{C}-\mathrm{S}$ bond. This is consistent with the changes in the corresponding distances of $\mathrm{Fe}-\mathrm{S}$ and $\mathrm{S}-\mathrm{C}$ bonds.

According to the X-ray absorption spectra, each Fe and NO group in $\mathbf{1}$ is likely to be in the form of $\mathrm{Fe}(\mathrm{I})$ and $\mathrm{NO}^{+}$with the Enemark-Feltham notation of $\{\mathrm{Fe}(\mathrm{NO})\} .{ }^{7}$ However, according to the magnetic measurement shown in Figure 3, there is only one unpaired electron in $\mathbf{1}\left(S_{\text {total }}=1 / 2\right)$ and no unpaired electron $\left(S_{\text {total }}=0\right)$ in $\mathbf{2}$. It is logical to assume that the oxidation takes place when this unpaired electron of complex $\mathbf{1}$ is removed from a singly occupied molecular orbital (SOMO). X-ray absorption spectra indicate that such oxidation process causes absorption edges of $\mathrm{Fe}, \mathrm{N}$, and $\mathrm{S}$ to be shifted slightly to higher energies. Thus, one predicts that the SOMO in complex 1 would be the combination of valence orbitals from $\mathrm{Fe}, \mathrm{N}$, and $\mathrm{S}$; this result will be further confirmed by the MO calculations.

EPR/ENDOR Spectroscopy. X-band EPR spectra of the $\mathbf{1}$ frozen in $\mathrm{CH}_{2} \mathrm{Cl}_{2}$ recorded under microwave power of $2 \mathrm{~mW}$ and modulation amplitude of $0.1 \mathrm{mT}$ at $100 \mathrm{kHz}$ are shown in Figure 7. Where $7 \mathrm{a}$ and $7 \mathrm{c}$ are the spectra taken at 5 and $77 \mathrm{~K}$ respectively; $7 \mathrm{~d}$ is the spectrum at $5 \mathrm{~K}$ on ${ }^{15} \mathrm{~N}$-labeled complex. $7 \mathrm{~b}$ and $7 \mathrm{e}$ are the simulated spectra corresponding to $7 \mathrm{a}$ and $7 \mathrm{~d}$. The EPR spectra at $5 \mathrm{~K}$ display a rhombic symmetry with evident hyperfine splitting. This signal does not consist of a fast-relaxing component; it could still be observed at $77 \mathrm{~K}$, in contrast to $\left[\mathrm{Fe}_{3} \mathrm{~S}_{4}\right]^{+}$clusters, where signals around $g=2.01$ are only observed at temperature below $30 \mathrm{~K}$. At $77 \mathrm{~K}$, the hyperfine features were averaged out due to the fast tumbling of the molecule with principal $g$ values of $g_{1}=2.011, g_{2}=$ 1.999 , and $g_{3}=1.986$ (Figure 7c). There are no further signals at lower field which identifies unquestionably a spin $S=1 / 2$ ground state at temperature above $5 \mathrm{~K}$. To clarify the origin of the observed multiline hyperfine pattern, we measured the EPR spectrum (Figure 7d) of ${ }^{15} \mathrm{~N}$-labeled 1, wherein all the nitrogen atoms are replaced by the ${ }^{15} \mathrm{~N}$ isotope $(>95 \%)$. In comparison of the ${ }^{15} \mathrm{~N}$-labeled $\mathbf{1}$ with that of the naturally abundant $\mathbf{1}$ (Figure 7, spectra $\mathrm{d}$ and a), though the overall line shape changes are muted, changes in the number of hyperfine lines and their resonant positions clearly indicate that the electron spin is coupled to the coordinated nitrogen atoms. We have attempted to simulate the spectra of $\mathbf{1}$ for both the ${ }^{14} \mathrm{~N}$ - and ${ }^{15} \mathrm{~N}$-labeled complexes based on $S=1 / 2$ rhombic models with two or three coordinated nitrogen atoms. A concurrent satisfactory fit to both ${ }^{14} \mathrm{~N}$ - (Figure $7 \mathrm{a}$ ) and ${ }^{15} \mathrm{~N}$ - (Figure $7 \mathrm{~d}$ ) data was only obtained for a rhombic model with three nonequivalent nitrogen atoms. The simulated EPR parameters are presented in Table 2. The simulated spectra (Figure 7, spectra b and e) yield rather small 


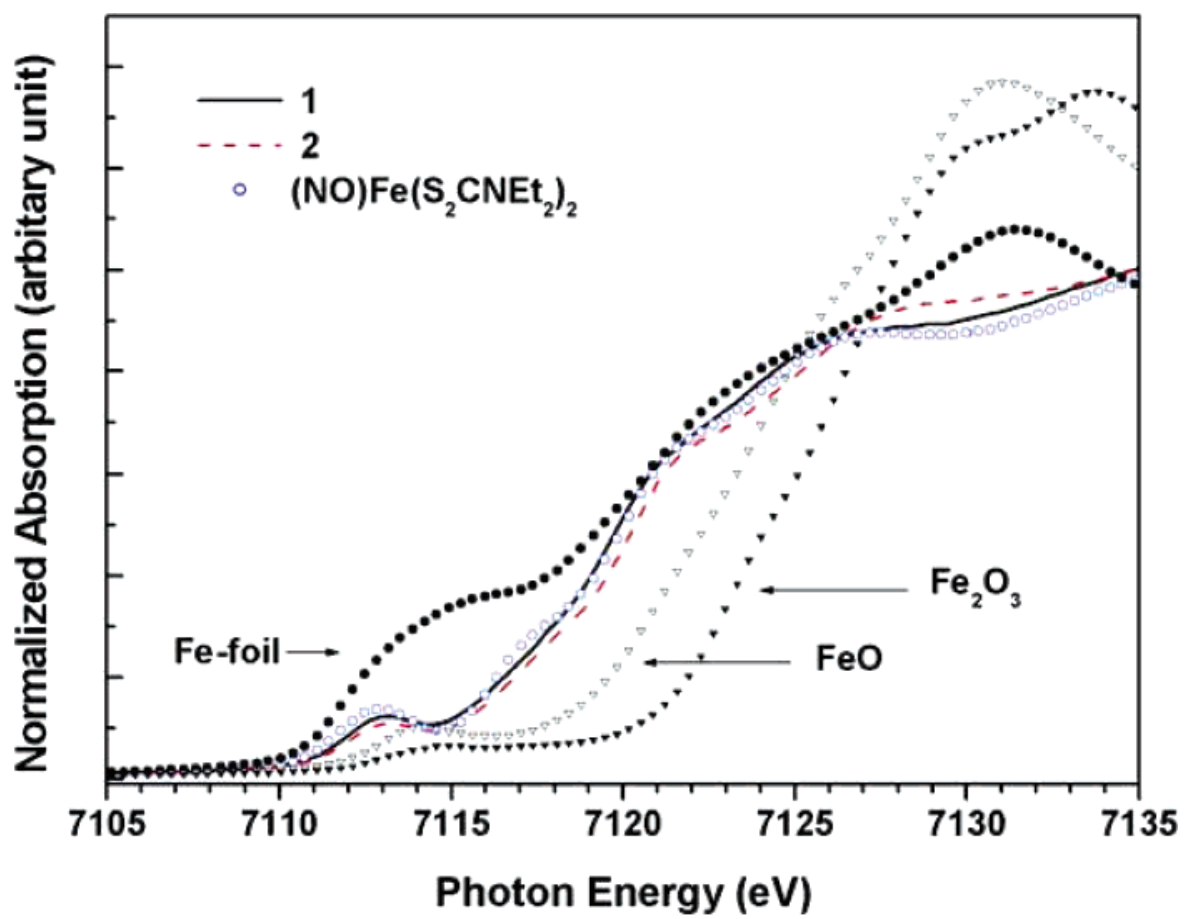

Figure 4. Fe K-edge spectra of the 1, 2, and some reference compounds. The solid (-) and dashed (---) lines are the $\mathbf{1}$ and $\mathbf{2}$, respectively. The solid circle $(\bullet)$ Fe foil; solid triangle $(\Delta) \mathrm{Fe}_{2} \mathrm{O}_{3}$; open triangle $(\triangle) \mathrm{FeO}$; open circle $(\mathrm{O})(\mathrm{NO}) \mathrm{Fe}\left(\mathrm{S}_{2} \mathrm{CNEt}_{2}\right)_{2}$.

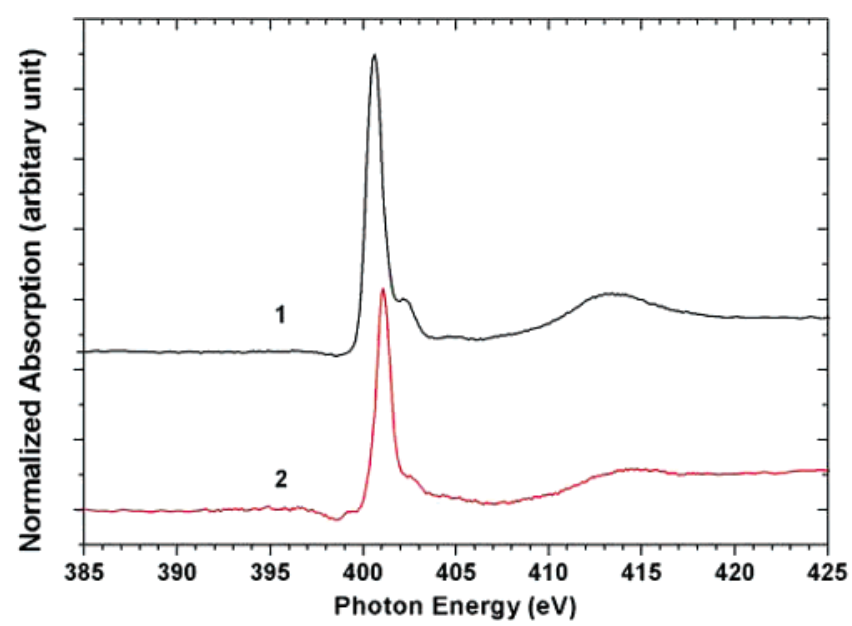

Figure 5. N K-edge spectra of the $\mathbf{1}$ (top) and $\mathbf{2}$ (bottom).

g-tensor anisotropy with principal $g$ values of $g_{1}=2.011, g_{2}=$ 1.999 , and $g_{3}=1.981$ which are consistent with the measured values at $77 \mathrm{~K}$. Thus, it points to a NO $2 \pi^{*}$-based SOMO in $\mathbf{1}$. But, a comparison with EPR data for free nitric oxide absorbed on the surface of $\mathrm{MgO}\left(g_{\|}=1.89, g_{\perp}=1.996, A_{\perp}=33 \mathrm{G}\right)$ and $\mathrm{ZnO}\left(g_{\|}=1.94, g_{\perp}=1.979, A_{\perp}=30 \mathrm{G}\right)$ reveals a significant reduction of the NO intrinsic hyperfine coupling constants in complex 1. This suggests that the odd electron which might be originated on fragment 1 as an NO radical is not only confined to the NO ligand but is also delocalized through the overlaps of $\mathrm{Fe}(3 \mathrm{~d})$ and $\mathrm{NO}\left(2 \pi^{*}\right)$ orbitals. The unpaired electron thus possesses metal d orbital characters enhancing the spin-lattice relaxation rate and results in the vanishing of the EPR signal at a temperature approximately about $120 \mathrm{~K}$. The observed nitrogen hyperfine couplings of fragments 2 and 3 are also attributed to the unpaired spin density delocalization originating from the $\mathrm{Fe}(\mathrm{NO})$ of fragment 1 .

The EPR results thus lead to a favorable description of $\{\mathrm{Fe}-$ NO $\}$ in fragment 1 as $S_{1}=1 / 2$, possibly $\left\{\mathrm{Fe}^{\mathrm{II}}(\bullet \mathrm{NO})\right\}^{7}$ and $\left\{\mathrm{Fe}^{\mathrm{I}}\right.$ $\left.(\mathrm{NO})^{+}\right\},{ }^{7}$ while fragments 2 and 3 are described as $S_{2,3}=1 / 2$, mainly $\left\{\mathrm{Fe}^{\mathrm{I}}(\mathrm{NO})^{+}\right\},{ }^{7}$ and are antiferromagnetically coupled with each other to give a $S_{\text {total }}=1 / 2$ ground state where all the Fe are in the low-spin state. This is imposed by the EPR results and a shorter distance between Fe atoms of fragments 2 and 3 ( 2.578 $\AA$ ) compared to those of fragment 1 and $2(\sim 2.782$ $\AA)$ and fragment 1 and $3(\sim 2.754 \AA)$. Therefore, three different nitrogen atoms means a predominate $\mathrm{NO}$ radical of $\left\{\mathrm{Fe}^{\mathrm{II}}\right.$ $(\bullet \mathrm{NO})\}^{7}$, a nitrosyl $\mathrm{NO}^{+}$of $\left\{\mathrm{Fe}^{\mathrm{I}}(\mathrm{NO})^{+}\right\}^{7}$, and a form between these two. It is unlikely to assume $S=3 / 2$ state for any one fragment, since this requires all three fragments to coupled together in order to give a $S_{\text {total }}=1 / 2$ ground state and that generally results in a much faster relaxation rate.

Additional evidence that supports delocalization of the unpaired electron spin density over the whole complex framework may come from measurements of the proton ENDOR spectra. In systems of low $g$ anisotropy, magnetically coupled protons are expected to produce ENDOR features mirrored about the free proton Larmor frequency $\nu_{\mathrm{N}}=g_{\mathrm{H}} \beta_{\mathrm{N}} H_{\mathrm{o}} / h(14.675 \mathrm{MHz}$ at $3446.5 \mathrm{G}$ ) and displaced by half of the value of the hyperfine coupling constants $\left(v_{ \pm}^{\mathrm{N}}=v_{\mathrm{N}} \pm A^{\mathrm{N}} / 2\right)$. Figure 8 presents an expanded proton ENDOR spectrum of $\mathbf{1}$ frozen in $\mathrm{CH}_{2} \mathrm{Cl}_{2}$ recorded at $5 \mathrm{~K}$ under $2 \mathrm{~mW}$ microwave power and $40 \mathrm{~W} \mathrm{RF}$ power. Hyperfine coupling in the matrix region $(<1 \mathrm{MHz})$ is shown in the inset of Figure 8. The prominent feature located at the Larmor frequency of the free proton with a nominal coupling of $\sim 0.5 \mathrm{MHz}$ is generally observed in solid-state ENDOR for close protons and is due mainly to dipolar interactions between the unpaired electron and surrounding solvent protons. The spectrum was recorded at a magnetic field 


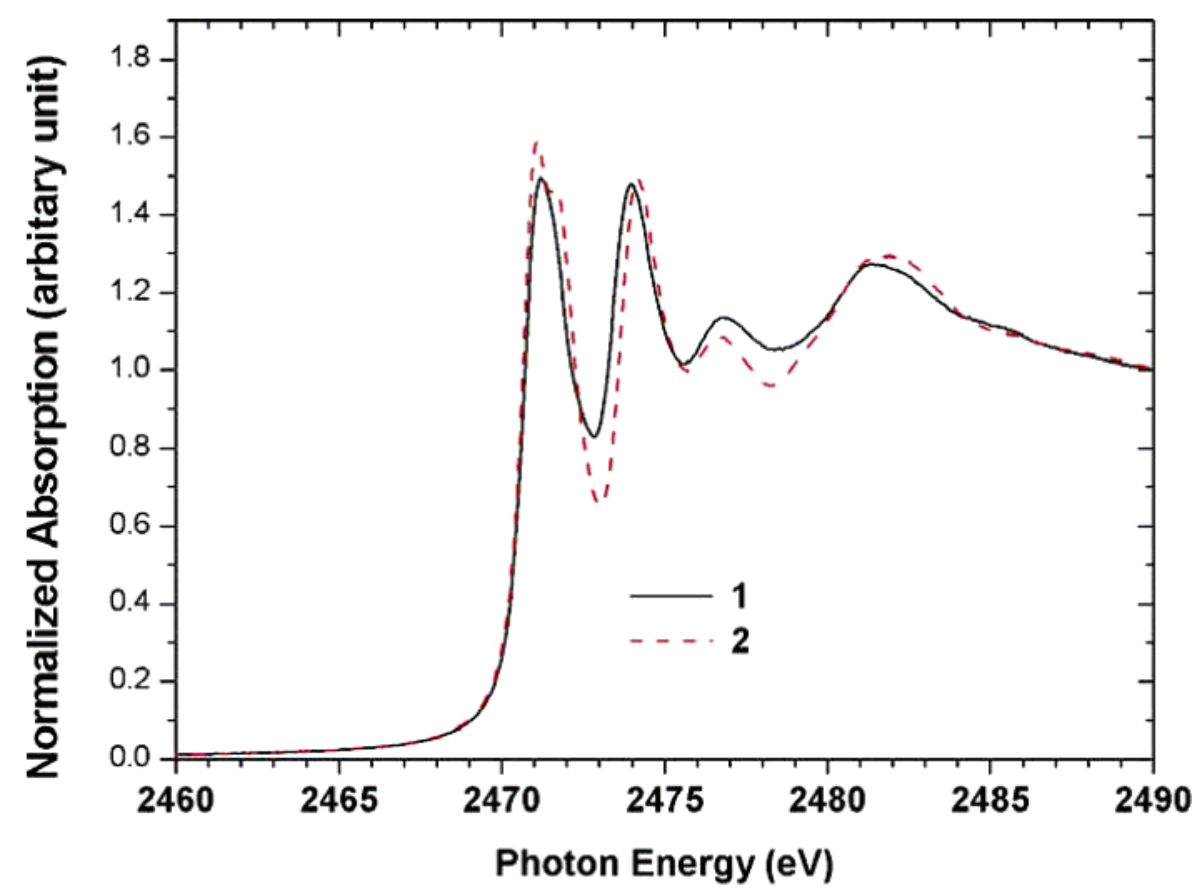

Figure 6. S K-edge spectra of the $\mathbf{1}$ (solid line) and $\mathbf{2}$ (dash line).

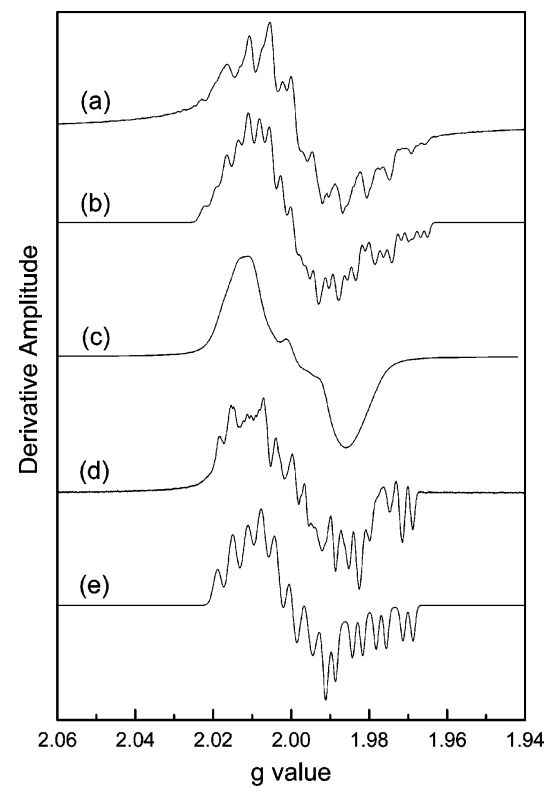

Figure 7. X-band EPR spectra and simulation of $\mathbf{1}$ frozen in $\mathrm{CH}_{2} \mathrm{Cl}_{2}$. Experimental spectra (a), (c), and (d) were obtained with a microwave power of $2 \mathrm{~mW}$ and modulation amplitude of $0.1 \mathrm{mT}$ at $100 \mathrm{kHz}$. (a) natural abundant 1 at $5 \mathrm{~K}$ and $9.5151 \mathrm{GHz}$ microwave frequency; (b) simulation of (a); (c) natural abundant $\mathbf{1}$ at $77 \mathrm{~K}$ and $9.4312 \mathrm{GHz}$; (d) ${ }^{15} \mathrm{~N}$ labeled $\mathbf{1}$ at $5 \mathrm{~K}$ and $9.520 \mathrm{GHz}$; (e) simulation of (d).

corresponding to $g=1.999$ where all directions of space contribute to the maximum of the EPR envelope. Therefore, ENDOR transitions (labeled as $a-a^{\prime}, b-b^{\prime}$, and $c-c^{\prime}$ through $\mathrm{f}-\mathrm{f}^{\prime}$ ) caused by intensity buildup correspond to principal values of hyperfine tensors of the benzene ring protons that are coupled to the delocalized unpaired spin density. Table 3 lists the ring protons hyperfine coupling constants given by the frequency separation between pairs of features that appear symmetrically about the ${ }^{1} \mathrm{H}$ Larmor frequency. These weak transitions are best observed at temperature below $20 \mathrm{~K}$ and under conditions of
Table 2. Principal Hyperfine Coupling Constants and Directions of the $g$ and ${ }^{14} \mathrm{~N}$ Hyperfine Tensors for Complex 1

\begin{tabular}{lll}
\hline & \multicolumn{1}{c}{ principle values } & \multicolumn{1}{c}{ Euler angles $^{a}$} \\
\hline $\begin{array}{l}\text { g-tensor } \\
\text { hyperfine tensor (Gauss) }\end{array}$ & $(2.011,1.999,1.981)$ & \\
fragment 1 $(\mathrm{Fe}(1)-\mathrm{N}(1)-\mathrm{O}(1))$ & $(9.2,6.6,15.6)$ & $(6,-150,18)$ \\
fragment 2 $\mathrm{Fe}(2)-\mathrm{N}(2)-\mathrm{O}(2))$ & $(3.3,9.4,1.9)$ & $(96,-86,63)$ \\
fragment 3 $(\mathrm{Fe}(3)-\mathrm{N}(3)-\mathrm{O}(3))$ & $(7,1,3.6)$ & $(70,5,-32)$ \\
\hline
\end{tabular}

${ }^{a}$ Euler angles, in (deg), are defined as in Goldstein (Goldstein, $\mathrm{H}$ Classical Mechanics; Addison Wesley: Reading MA, 1967).

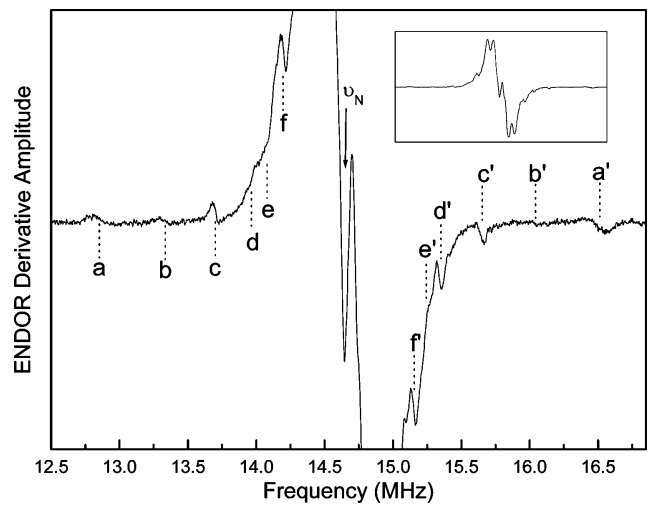

Figure 8. Proton ENDOR spectra of 1 frozen in $\mathrm{CH}_{2} \mathrm{Cl}_{2}$. The spectrum was taken at the maximum EPR absorption corresponding to $g=1.999$ of Figure 7. The ${ }^{1} \mathrm{H}$ Larmor frequency $\left(v_{\mathrm{N}}\right)$ is $14.675 \mathrm{MHz}$. Conditions: microwave frequency $9.6427 \mathrm{GHz} ; H_{\mathrm{o}}=3446.5 \mathrm{G}$; microwave powder, 2 $\mathrm{mW}$; radio frequency power, $40 \mathrm{~W}$; FM amplitude, $20 \mathrm{kHz}$; number of scans, four; temperature, $5 \mathrm{~K}$. Six different ${ }^{1} \mathrm{H}$ doublets (labeled as $\mathrm{a}-\mathrm{a}^{\prime}$, $\mathrm{b}-\mathrm{b}^{\prime}$, and $\mathrm{c}-\mathrm{c}^{\prime}$ through $\mathrm{f}-\mathrm{f}^{\prime}$ ) are seen split symmetrically about $\nu_{\mathrm{N}}$.

high RF modulation and power which enhance the signal-tonoise ratio at the expanse of spectral resolution.

Tentative assignments of the ring $\alpha$-protons hyperfine tensors are made by comparison with the magnitude and apportioning the principal values given in Table 3 according to established physical models. For $\alpha$-protons, one expects a rhombic principal hyperfine tensor component pattern of $0.5 a_{\text {iso }}, 1.0 a_{\text {iso }}$, and $1.5 a_{\text {iso }}$ 
Table 3. Proton Hyperfine Coupling Constants and Assignments for Complex 1 Determined by CW-ENDOR

\begin{tabular}{ccc}
\hline transitions & $\begin{array}{c}\text { hyperfine constants } \\
(\mathrm{MHz})\end{array}$ & $\begin{array}{c}\text { assignments } \\
\text { protons bonded to }\end{array}$ \\
\hline $\mathrm{a}, \mathrm{a}^{\prime}$ & $A_{X}=-3.66$ & $\mathrm{C}(2,5,8,11)$ \\
$\mathrm{b}, \mathrm{b}^{\prime}$ & $A_{Z}=-2.69$ & $\mathrm{C}(2,5,8,11)$ \\
$\mathrm{c}, \mathrm{c}^{\prime}$ & $A_{X}=-1.93$ & $\mathrm{C}(3,4,9,10)$ \\
$\mathrm{d}, \mathrm{d}^{\prime}$ & $A_{Z}=-1.33$ & $\mathrm{C}(3,4,9,10)$ \\
$\mathrm{e}, \mathrm{e}^{\prime}$ & $A_{Y}=-1.23$ & $\mathrm{C}(2,5,8,11)$ \\
$\mathrm{f}, \mathrm{f}^{\prime}$ & $A_{Y}=-0.88$ & $\mathrm{C}(3,4,9,10)$ \\
& & \\
\hline
\end{tabular}
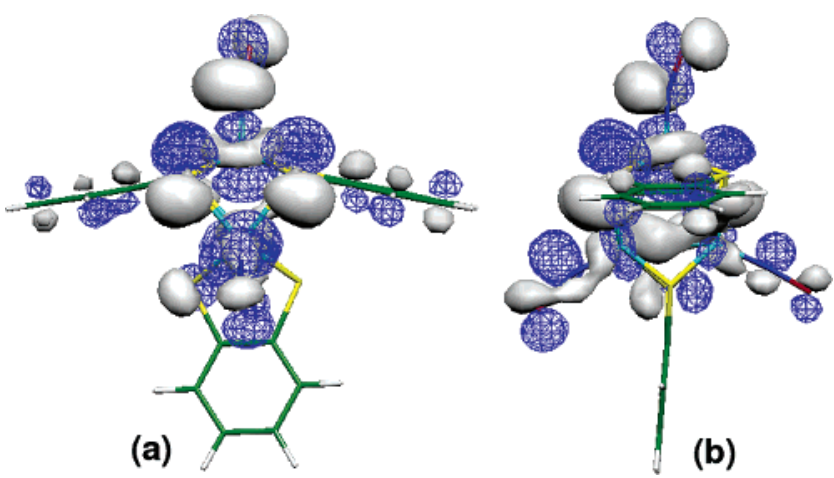

Figure 9. Wave function of SOMO of $\mathbf{1}$, view (a) along the pseudo-mirror; (b) perpendicular to (a).

that are along the $\mathrm{C}-\mathrm{H}$ bond $\left(A_{Y}\right)$, parallel to the axis of the $\mathrm{p}_{z}$ orbital $\left(A_{Z}\right)$, i.e., normal to the benzene ring, and perpendicular to the $\mathrm{C}-\mathrm{H}$ bond $\left(A_{X}\right)$, respectively. According to this rule, the grouping of observed hyperfine couplings into the $A_{X}, A_{Y}$, and $A_{Z}$ components for two sets of distinguishable protons are presented in Table 3. Also, for $\alpha$-protons, we expect that the sign of the isotropic hyperfine coupling will be negative. The hyperfine tensors obtained from the ENDOR transition frequencies are in good correspondence with the physical model for $\alpha$-protons. We therefore make the assignments of these ENDOR features of the benzene ring protons, and that establishes the spin delocalization picture of fragment 1 of $\mathbf{1}$.

MO Calculation. Both unrestricted and restricted open shell MO calculations of $\mathbf{1}$ have been performed by taking the geometry from the respective crystal structure. The overall results are roughly the same. The unrestricted one yields the expectation value of total spin quantum number, ${ }^{22}\left\langle S^{2}\right\rangle$, of 0.78 , which is close to the ideal eigenvalue of 0.75 with $S=1 / 2$. The atomic charge analysis gives about the same charge on each iron atom of $\mathbf{1}$, no matter what types of atomic partition is taken into account. The calculated principal $g$-values, $g_{1}=2.011, g_{2}$ $=1.993$, and $g_{3}=1.983$, at ground state are in good agreement with the ones derived from EPR. The SOMO of $\mathbf{1}$ is depicted in Figure 9, where the major contribution is obviously from the fragment 1 with $\mathrm{Fe}(1)$ and its associated ligands, some contributions from $\mathrm{Fe}-(\mathrm{NO})$ of fragment 2 and 3. Thus the unpaired electron of $\mathbf{1}$ is mainly located on the fragment 1 , $\left\{(\mathrm{NO}) \mathrm{Fe}(1)\left(\mathrm{S}_{2} \mathrm{C}_{6} \mathrm{H}_{4}\right)\right\}$, but only partially delocalized to the other two $\mathrm{Fe}(\mathrm{NO})$ parts. On the contrary, the highest occupied

(22) (a) Bulo, R. E.; Ehlers, A. W.; Grimme, S.; Lammertsma, K. J. Am. Chem Soc. 2002, 124, 13903. (b) For calculating the $\left\langle S^{2}\right\rangle$ values, the following formula was implemented in the ADF algorithm: $\left\langle S^{2}\right\rangle_{\mathrm{uhf}}=\left\langle S^{2}\right\rangle_{\text {exact }}+$ $N^{\beta}-\sum_{i}^{N} \sum_{j}^{N}\left|S_{i j}^{\alpha \beta}\right|$ and $\left\langle S^{2}\right\rangle_{\text {exact }}=\left[\left(N^{\alpha}-N^{\beta}\right) / 2\right]\left[\left(N^{\alpha}-N^{\beta}\right) / 2+1\right] . S_{i j}$ is the overlap integral of $\alpha$-orbital $i$ with $\beta$-orbital $j$, and $N$ is the number of electrons where $N^{\alpha} \geq N^{\beta}$. See: Szabo, A.; Ostlund, N. S. Modern Quantum Chemistry, 1st revised ed.; McGraw-Hill: New York, 1989; p 107.
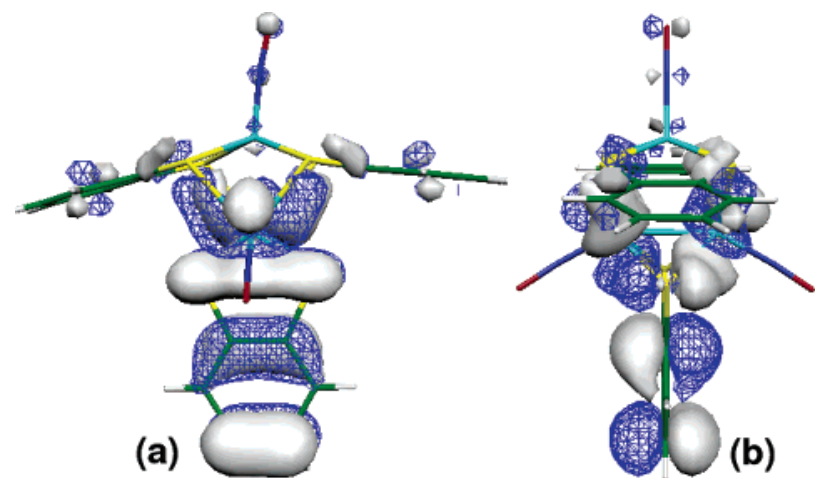

Figure 10. Wave function of HOMO of the cation of 2, view (a) along the mirror; (b) perpendicular to (a).

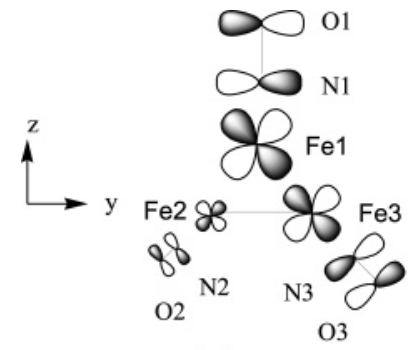

(a)

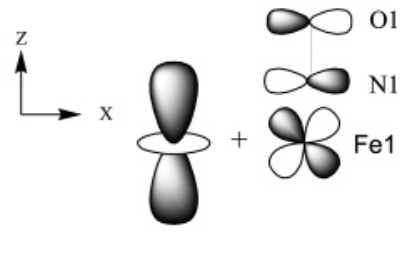

(b)
Figure 11. Some important orbital coefficients of SOMO at (a) $Y-Z$ plane (b) $X-Z$ plane. The selected SOMO coefficients are listed in the Supporting Information.

molecular orbital (HOMO) of $\mathbf{2}$ is principally contributed from d-orbitals of $\mathrm{Fe} 2$ and $\mathrm{Fe} 3$ and only slightly from the fragment 1 as shown in Figure 10. In fact, it is quite similar to the orbital next (lower energy) to the SOMO in $\mathbf{1}$. Detailed analysis of the coefficients of SOMO reveals that the orbital is predominately contributed from fragment 1 including $\mathrm{Fe}(1)-\mathrm{N}(1)-\mathrm{O}(1)$ and the sulfur atoms of two thiolates; roughly $30 \%, 12 \%$, and $21 \%$ for Fe, $\mathrm{NO}$, and $\mathrm{S}$, respectively. The other important contribution comes from $\mathrm{Fe}(3)-\mathrm{N}(3)-\mathrm{O}(3)$ where $13 \%$ and $8 \%$ from $\mathrm{Fe}(3)$ and $\mathrm{N}(3) \mathrm{O}(3)$, respectively. The large coefficients are all from d-orbitals of $\mathrm{Fe}$ and $\pi^{*}$ orbitals of $\mathrm{NO}$; this means the unpaired electron is delocalized among Fe atoms and NO ligands through $\mathrm{d}-\mathrm{d}$ and $\mathrm{d}-\pi^{*}$ interactions. The most important part of interatomic interactions of SOMO are depicted in Figure 11. It is obvious that the $d-p \pi^{*}$ characters between $\mathrm{Fe}(1)$ and $\mathrm{N}(1)$ are in antibonding character with both $\mathrm{d}_{y z}$ and $\mathrm{d}_{x z}$ of Fe. In addition, all the NO bonds are also in antibonding character. More importantly, the biggest coefficient in SOMO is on the $\mathrm{d}_{z^{2}}$ of $\mathrm{Fe}(1)$ which amounts to $23 \%$ of contribution. The removal of one electron from such an orbital yields the shortening and strengthening of the $\mathrm{NO}$ bond with much higher $v_{\mathrm{NO}}$ stretching frequency in 2. It also yields the shortening of $\mathrm{Fe}-\mathrm{N}$ bond. However, the shortening of $\mathrm{Fe}-\mathrm{Fe}$ distances is not so straightforward due to many $\mathrm{d}-\mathrm{d}$ interactions; some are bonding, the others are antibonding. The coefficients are, in general, very large, indicating that the unpaired electron does locate predominately on the $\mathrm{Fe}$ atoms, especially $\mathrm{Fe}(1)$, which gives the confirmation of having low-spin $\mathrm{d}^{7} \mathrm{Fe}(\mathrm{I})$ observed from XAS. The three possible different forms of NO deduced from the hyperfine splittings of EPR spectra are realized to be corresponding to $\mathrm{NO}$ radical, $\mathrm{NO}^{+}$, or a resonance hybrid. The $\pi^{*}{ }_{\mathrm{NO}}$ is always overlapped with Fe d-orbitals as shown in Figure 11, 
the symbol of $\{\mathrm{Fe}(\mathrm{NO})\}^{7}$ speaks well of such spin delocalization character in this complex. However, the calculated spin densities at $\mathrm{Fe}(1), \mathrm{Fe}(2)$, and $\mathrm{Fe}(3)$ are $0.60,-0.15$, and 0.25 , respectively, whereas at $\mathrm{N}(1), \mathrm{N}(2)$, and $\mathrm{N}(3)$ the spin densities are only 0.04 , 0.02 , and 0.05 .

\section{Conclusion}

The neutral trinuclear $\mathrm{Fe}$-thiolate-nitrosyl 1 was obtained from the protonation of a mononuclear complex [PPN][(NO)$\left.\mathrm{Fe}\left(\mathrm{S}, \mathrm{S}-\mathrm{C}_{6} \mathrm{H}_{4}\right)_{2}\right]$, and 2 was subsequently obtained by the oxidation of $\mathbf{1}$. The coordination environment of $\left[\mathrm{FeS}_{4}(\mathrm{NO})\right]$ units remains intact when $\mathbf{1}$ was oxidized to yield $\mathbf{2}$; however, all of the $\mathrm{Fe}-\mathrm{Fe}, \mathrm{Fe}-\mathrm{N}$, and $\mathrm{Fe}-\mathrm{S}$ distances are shortened significantly, especially around $\mathrm{Fe}(1)$. Taking the results from $\mathrm{X}$-ray diffraction, X-ray absorption, magnetic measurement, EPR measurement, and the $\mathrm{MO}$ calculation, each $[\mathrm{Fe}(\mathrm{NO})]$ moiety of $\mathbf{1}$ is best described as $\{\mathrm{Fe}(\mathrm{NO})\},{ }^{7}$ i.e. an unpaired electron delocalized between $\mathrm{Fe}$ and NO via $\mathrm{d}-\pi^{*}$ interaction. No evidence of any possibility of quartet ground state $(S=3 / 2)$ existed based on magnetic and EPR measurements; each iron is mainly in a low-spin $\mathrm{d}^{7} \mathrm{Fe}^{\mathrm{I}}$, but $\mathrm{Fe}(2)$ and $\mathrm{Fe}(3)$ are antiferromagnetically coupled with each other. Due to the change of geometry upon one-electron oxidation of $\mathbf{1}$ to $\mathbf{2}$, and based on the wavefunction of the SOMO of $\mathbf{1}$, the unpaired electron in $\mathbf{1}$ is, presumably, delocalized among three [ $\mathrm{Fe}(\mathrm{NO})]$ moieties together with the two bidentate dithiolates of $\mathrm{Fe}(1)$, but with the majority of contribution coming from the $\mathrm{Fe}(1)$ fragment. The SOMO is mainly contributed from the $d-p \pi^{*}$ overlap between $\mathrm{Fe}$ and $\mathrm{N}$ or $\mathrm{S}$. However, the $\mathrm{d}-\mathrm{d}$ interactions between the $\mathrm{Fe}$ atoms gives a net antibonding character between $\mathrm{Fe}(1)$ and $\mathrm{Fe}(2)$ or $\mathrm{Fe}(1)$ and $\mathrm{Fe}(3)$. Indeed, the geometry around the $\mathrm{Fe}(1)$ changes the most from $\mathbf{1}$ to $\mathbf{2}$ when the removal of the unpaired electron is exercised. The spin density is indeed allocated predominately on $\mathrm{Fe}$ atoms.

\section{Experimental Section}

Manipulations, reactions, and transfers of samples were conducted under nitrogen according to standard Schlenk techniques or in a glovebox (argon gas). Solvents were distilled under nitrogen from appropriate drying agents (methylene chloride, diethyl ether, and methanol from $\mathrm{CaH}_{2}$, acetonitrile from $\mathrm{CaH}_{2}-\mathrm{P}_{2} \mathrm{O}_{5}$, hexane and tetrahydrofuran (THF) from sodium benzophenone) and were stored in dried, $\mathrm{N}_{2}$-filled flasks over $4 \AA$ molecular sieves. Nitrogen was purged through these solvents before use. Solvent was transferred to a reaction vessel via a stainless steel cannula under positive pressure of $\mathrm{N}_{2}$. The reagents iron pentacarbonyl, sodium nitrite, 1,2-benzenedithiol, bis(triphenylphosphoranylidene)ammonium chloride, fluoroboric acid, sodium borohydride (Lancaster/Aldrich) were used as received. Complex $[\mathrm{PPN}]\left[\mathrm{Fe}(\mathrm{CO})_{3}(\mathrm{NO})\right]$ was synthesized and characterizd by published procedures. ${ }^{18}$ Infrared spectra of the $v(\mathrm{NO})$ stretching frequencies were recorded on a Perkin-Elmer model spectrum one B spectrophotometer with sealed solution cells $(0.1 \mathrm{~mm})$ and $\mathrm{KBr}$ windows. HewlettPackard 71 and GBC Cintra 10e spectrophotometers were used to record the UV-vis spectra of each complex. ${ }^{1} \mathrm{H}$ NMR spectra were recorded on a Bruker model AC 200 spectrometer. Analyses of carbon, hydrogen, and nitrogen were obtained with a $\mathrm{CHN}$ analyzer (Heraeus).

Preparation of $\left[(\mathbf{O N}) \mathbf{F e}\left(\mu-\mathrm{S}, \mathrm{S}-\mathrm{C}_{6} \mathbf{H}_{4}\right)\right]_{3}(\mathbf{1}) . \mathrm{HBF}_{4}(73 \mu \mathrm{L}, 0.6 \mathrm{mmol})$ was slowly added to the THF $(10 \mathrm{~mL})$ solution of [PPN][(NO)Fe(S,S$\left.\left.\mathrm{C}_{6} \mathrm{H}_{4}\right)_{2}\right](0.611 \mathrm{~g}, 0.6 \mathrm{mmol})^{17}$ by syringe, and the mixture stirred for $2 \mathrm{~h}$ at ambient temperature. The color of the reaction solution changed from red brown to greenish brown. The reaction was then monitored with FTIR. The IR spectrum ( $\left.\nu_{\mathrm{NO}}: 1760 \mathrm{~cm}^{-1}(\mathrm{THF})\right)$ was assigned to the formation of neutral $\left[(\mathrm{ON}) \mathrm{Fe}\left(\mu-\mathrm{S}, \mathrm{S}-\mathrm{C}_{6} \mathrm{H}_{4}\right)\right]_{3}(\mathbf{1})(0.163 \mathrm{~g}, 40 \%)$.
Diethyl ether was then added to the solution and filtered through Celite to remove the white insoluble solid. The filtrate (THF-diethyl ether mixture) stood at $-15{ }^{\circ} \mathrm{C}$ for 4 weeks and led to greenish brown crystals suitable for single-crystal X-ray diffraction. IR $\left(v_{\mathrm{NO}}\right)$ : $1760 \mathrm{br} \mathrm{cm}^{-1}$ (THF); $1751 \mathrm{br} \mathrm{cm}^{-1}$ (KBr). ${ }^{1} \mathrm{H}$ NMR $\left(\mathrm{CDCl}_{3}\right)$ : $\delta 2.61$ (br), -0.192 (br) ppm $\left(\mathrm{C}_{6} \mathrm{H}_{4}\right)$. Absorption spectrum $\left(\mathrm{CH}_{2} \mathrm{Cl}_{2}\right)\left[\lambda_{\max , \mathrm{nm}}\left(\epsilon, \mathrm{M}^{-1} \mathrm{~cm}^{-1}\right)\right]$ : 303 (33556), 357 (21556), 408 (16455) 589 (2466). Anal. Calcd for $\mathrm{C}_{18} \mathrm{H}_{12} \mathrm{O}_{3} \mathrm{~N}_{3} \mathrm{~S}_{6} \mathrm{Fe}_{3}$ : C, 31.88; H, 1.78; N, 6.20. Found: C, 32.56; H, 1.89; N, 5.83 .

Preparation of $\left[(\mathrm{ON}) \mathrm{Fe}\left(\mu-\mathrm{S}, \mathrm{S}-\mathrm{C}_{6} \mathrm{H}_{4}\right)\right]_{3}\left[\mathrm{PF}_{6}\right]$ (2). Compound 1

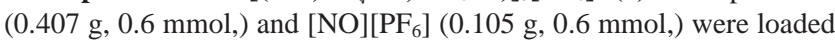
in a flask and dissolved in $10 \mathrm{~mL}$ of $\mathrm{CH}_{2} \mathrm{Cl}_{2}$. The mixture was then stirred for $1 \mathrm{~h}$. The color of the solution changed from greenish brown to dark green. The reaction was monitored afterward with FTIR immediately. IR spectrum $\left(\nu_{\mathrm{NO}}: 1836,1857 \mathrm{~cm}^{-1}\left(\mathrm{CH}_{2} \mathrm{Cl}_{2}\right)\right)$ corresponds to the formation of $2(0.286 \mathrm{~g}, 58 \%)$. The solution was filtered through Celite, and then diethyl ether was added to precipitate the dark-green solid. Diffusion of hexane-diethyl ether into a saturated $\mathrm{CH}_{2} \mathrm{Cl}_{2}-$ $\mathrm{MeOH}$ solution of $\mathbf{2}$ at $-15{ }^{\circ} \mathrm{C}$ gave dark-green crystals suitable for single-crystal X-ray diffraction. IR $\left(v_{\mathrm{NO}}\right)$ : $1836,1857 \mathrm{~cm}^{-1}\left(\mathrm{CH}_{2} \mathrm{Cl}_{2}\right)$ 1821, $1857 \mathrm{~cm}^{-1}(\mathrm{KBr}) .{ }^{1} \mathrm{H}$ NMR $\left(\mathrm{CDCl}_{3}\right): \delta 7.80(\mathrm{~m}), 7.48(\mathrm{~m}), 6.86$ (br), 5.28 (br) ppm $\left(\mathrm{C}_{6} \mathrm{H}_{4}\right)$. Absorption spectrum $\left(\mathrm{CH}_{2} \mathrm{Cl}_{2}\right)\left[\lambda_{\max }, \mathrm{nm}-\right.$ $\left(\epsilon, \mathrm{M}^{-1 \mathrm{~cm}-1}\right)$ ]: 351 (32857), 402 (21950), 572 (4245). Anal. Calcd for $\mathrm{C}_{18} \mathrm{H}_{12} \mathrm{PFe}_{3} \mathrm{~N}_{3} \mathrm{O}_{3} \mathrm{~S}_{6} \mathrm{~F}_{6}: \mathrm{C}, 26.26 ; \mathrm{H}, 1.47 ; \mathrm{N}, 5.10$. Found: C, 27.61; $\mathrm{H}, 2.00 ; \mathrm{N}, 5.28$.

Reduction of $\left[(\mathbf{O N}) \mathbf{F e}\left(\mu-\mathrm{S}, \mathrm{S}-\mathrm{C}_{6} \mathbf{H}_{4}\right)\right]_{3}\left[\mathbf{P F}_{6}\right] . \mathrm{A} \mathrm{CH}_{2} \mathrm{Cl}_{2}$ solution $(6$ $\mathrm{mL})$ containing $0.329 \mathrm{~g}(0.4 \mathrm{mmol})$ of $2,0.151 \mathrm{~g}(0.4 \mathrm{mmol})$ of [Na]$\left[\mathrm{BH}_{4}\right]$, and $0.229 \mathrm{~g}(0.4 \mathrm{mmol})$ of $[\mathrm{PPN}][\mathrm{Cl}]$ was stirred at ambient temperature for $1 \mathrm{~h}$. The color of the solution changed from dark green to greenish brown. Diethyl ether $(6 \mathrm{~mL})$ was added to the solution, and then the mixture was filtered through Celite to remove the insoluble solid. The filtrate $\left(\mathrm{CH}_{2} \mathrm{Cl}_{2}\right.$-diethyl ether mixture) was then dried under vacuum to obtain green-brown solid. The IR $\left(\nu_{\mathrm{NO}}: 1760 \mathrm{br}(\mathrm{THF})\right.$; $1751 \mathrm{br} \mathrm{cm}{ }^{-1}(\mathrm{KBr})$ ), UV-vis (absorption spectrum $\left(\mathrm{CH}_{2} \mathrm{Cl}_{2}\right)\left[\lambda_{\max }\right.$, $\mathrm{nm}]: 303,357,408,589)$ and ${ }^{1} \mathrm{H}$ NMR spectrum $(\delta 2.61(\mathrm{br}),-0.19$ (br) ppm $\left.\left(\mathrm{C}_{6} \mathrm{H}_{4}\right)\left(\mathrm{CDCl}_{3}\right)\right)$ indicated the formation of $\mathbf{1}$.

Magnetic Measurements. The magnetization data were recorded on a SQUID magnetometer (MPMS XL Quantum Design company) with an external magnetic field of $1.0 \mathrm{~T}$ in the temperature ranges of $2-300 \mathrm{~K}$. The experimental magnetic susceptibility data were corrected for diamagnetism.

X-ray Absorption Spectroscopy. All X-ray absorption experiments were carried out at the National Synchrotron Radiation Research Center (NSRRC), Hsinchu, Taiwan. All spectra were recorded at room temperature. For Fe K-edge measurements, the experiment was performed in transmission mode at the BL-17C wiggler beamline with a double crystal monochromator of $\operatorname{Si}(111)$. The energy resolution $\Delta E / E$ is $2 \times 10^{-4}$. High harmonics were removed by using Rh-coated mirrors. The energy is scanned from 6.912 to $8.105 \mathrm{KeV}$ using a gas-ionization detector. A reference Fe foil is always used as an internal standard for the calibration of energy. The ion chambers used to measure the incident $\left(I_{0}\right)$ and transmitted $(I)$ intensities were filled with a mixture of $\mathrm{N}_{2}$ and $\mathrm{He}$ gas and a mixture of $\mathrm{N}_{2}$ and $\mathrm{Ar}$ gas, respectively.

The S K-edge data were measured in fluorescence mode at BL-15B $\mathrm{DCM}$ with $\mathrm{Si}(111)$. The energy resolution $\triangle E / E$ is $1.4 \times 10^{-4}$. The energy is scanned from 2.4 to $3.0 \mathrm{KeV}$ using Lytle detector in fluorescence mode. The sample chamber is filled with high purity-He gas to avoid the air absorption. Samples were ground to powder from single crystals, and secured onto a piece of cellophane tape. The photon energy was calibrated to the maximum of the first preedge feature of $\mathrm{Na}_{2} \mathrm{~S}_{2} \mathrm{O}_{3} \cdot 5 \mathrm{H}_{2} \mathrm{O}$ at $2472.02 \mathrm{eV}$.

For N K-edge absorption, the data were collected at the 6-m highenergy spherical grating monochromator (HSGM) beamline with $10 \times 10 \mu \mathrm{m}$ opening slits, corresponding to $\sim 0.08 \mathrm{eV}$ energy resolution. Samples were ground to powder from single crystals, then secured onto conducting tape, and subjected to an ultrahigh vacuum chamber $\left(10^{-9}\right.$ 
Torr). The spectra were recorded in total electron yield mode with a microchannel plate as detector. Each spectrum was calibrated by using the known absorption at $531.3 \mathrm{eV}$ of $\mathrm{Cr}$ oxides.

EPR/ENDOR Measurements. EPR measurements were performed at X-band using a Bruker EMX spectrometer equipped with a Bruker TE102 cavity. The microwave frequency was measured with a HewlettPackard 5246L electronic counter. During EPR measurements, the temperature was maintained at $5 \mathrm{~K}$ by using an Advanced Research System Helitran continuous flow cryostat $(3.2-200 \mathrm{~K})$ or at $77 \mathrm{~K}$ by immersion of the EPR sample tube into liquid nitrogen containing a finger Dewar. The EPR instrument settings are shown in the figure legend. ENDOR spectra were recorded with a Bruker DICE ENDOR assembly equipped with a Bruker $\mathrm{TM}_{110}$ ENDOR cavity fitted with a home-built RF coil for introducing the RF radiation in conjunction with a high-power RF amplifier (ENI 3200L) to generate the CW $B_{2}$ field in the cavity. ENDOR spectra were collected in frequency modulation mode by stepping the RF frequency over the range from 0.5 to 50 $\mathrm{MHz}$. The ENDOR instrument settings are shown in the figure legend.

MO Calculation. DFT calculations were carried out by Amsterdam Density Functional 2004.01 (ADF) ${ }^{23}$ with the generalized gradient approximation (GGA). The corrections of LDA and GGA parts are taken fromVWN ${ }^{24}$ and BP. ${ }^{25,26}$ The SCALAR ZORA is used for relativistic corrections. A close shell MO calculation of the cation of 2 is performed. Both unrestricted and restricted open shell MO calculations of 1 have been computed. The triple- $\zeta$ Slater type function complemented with two polarization functions (TZ2P) are used for all atoms. Geometric coordinates of each complex were taken from the single-crystal structure. The coordinate system employed is such that the origin is set at the $\mathrm{Fe}(1)$ atom; the $z$-axis is collinear with $\mathrm{Fe}(1)$ $\mathrm{N}(1)$ bond; the $x$-axis is perpendicular to $z$-axis and at the bisection of $\angle \mathrm{S}(1)-\mathrm{Fe}-\mathrm{S}(2)$. Atomic positions of $\mathrm{N}$ and $\mathrm{O}$ atoms are optimized

(23) (a) teVelde, G.; Bickelhaupt, F. M.; van Gisbergen, S. J. A.; Guerra, C. F.; Baerends, E. J.; Snijders, J. G.; Ziegler, T. J. Comput. Chem. 2001, 22, 931. (b) Fonseca Guerra, C.; Snijders, J. G.; teVelde, G.; Baerends, E. J. Theor. Chim. Acta 1998, 99, 391.

(24) Vosko, S. H.; Wilk, L.; Nusair, M. Can. J. Phys. 1980, 58, 1200.

(25) Becke, A. D. Phys. Rev. A 1988, 38, 3098.

(26) Perdew, J. P.; Yang, W. Phys. Rev. B 1986, 33, 8800.

(27) Sheldrick, G. M. SADABS, Siemens Area Detector Absorption Correction Program; University of Göttingen: Germany, 1996.

(28) Sheldrick, G. M. SHELXTL, Program for Crystal Structure Determination Siemens Analytical X-ray Instruments Inc.: Madison, WI, 1994. due to the uncertainty in the crystal data. The optimization criteria are as following: (i) the difference in the total energy between two successive cycles has to be less than 0.001 hartree; (ii) the maximal difference in the norm of the gradient between two successive cycles has to be less than 0.01 hartree/A; (iii) the maximal difference in the Cartesian coordinate between two successive cycles has to be less than $0.01 \AA$.

X-ray Diffraction. Crystallographic data and the detailed atomic parameters of complexes $\mathbf{1}$ and $\mathbf{2}$ are summarized in the Supporting Information (Table S1). The crystals of $\mathbf{1}$ and $\mathbf{2}$ chosen for X-ray diffraction studies are measured in size $0.28 \mathrm{~mm} \times 0.28 \mathrm{~mm} \times 0.10$ $\mathrm{mm}$, and $0.18 \mathrm{~mm} \times 0.16 \mathrm{~mm} \times 0.09 \mathrm{~mm}$, respectively. Each crystal was mounted on a glass fiber and quickly coated in epoxy resin. Unit cell parameters were obtained by least-squares refinement. Diffraction measurements for $\mathbf{1}$ and $\mathbf{2}$ were carried out on a SMART CCD diffractometer with graphite-monochromated Mo K $\alpha$ radiation $(\lambda=$ $0.7107 \AA$ ) and $\theta$ between $1.84^{\circ}$ and $27.50^{\circ}$ for $\mathbf{1}$, and between $1.59^{\circ}$ and $27.50^{\circ}$ for 2 . Least-squares refinement of the positional and anisotropic thermal parameters of all non-hydrogen atoms and fixed hydrogen atoms was based on $F^{2}$. A SADABS ${ }^{27}$ absorption correction was made. The SHELXTL ${ }^{28}$ structure refinement program was employed. In the case of $\mathbf{1}$, the oxygen atoms in all $\mathrm{NO}$ groups were found to be disordered, two positions were modeled in $50 \%$ each with positional coordinates refined.

Acknowledgment. We thank the National Science Council (Taiwan) for the financial support of this work. We also thank NSRRC and NCHC for their support on the hardware and software applied in this work.

Supporting Information Available: X-ray crystallographic files in CIF format for the structural determinations of complexes $\mathbf{1}$ and $\mathbf{2}$, include crystallographic data, refinement parameters, and bond distances/angles; crystallographic data of complexes $\mathbf{1}$ and $\mathbf{2}$, the SOMO coefficients and compositions of the selected atomic orbitals of SOMO, Tables S1, S2, and S3, respectively. This material is available free of charge via the Internet at http://pubs.acs.org.

JA065401E 